\title{
Some Factors Affecting Incidence of Leaf Spot of Turmeric by
}

\author{
Taphrina maculans Butler \\ Rajendra UpadhyaY* and M. S. PAvgi* \\ Rajendra UPADHYAY* M. S. PAVGI*: Taphrina maculans とよる \\ ウコン斑点病の発生に及ぼす2,3の要因
}

\begin{abstract}
Incidence of leaf spot disease of turmeric (Curcuma longa L.) incited by Taphrina maculans Butler has been demonstrated to be influenced by the amount of soil-borne in. oculum as well as prevailing environmental conditions. Age of the host leaves becomes inconsequential, since they remain susceptible to infection over a long period until moisture remains available. Early appearance and severity of disease are conditioned by the concentration of effective inoculum in the soil. Moist cloudy weather with a temperature of $25-30^{\circ} \mathrm{C}\left(30-25^{\circ} \mathrm{C}\right.$ from August to September) prevalent in this area is conducive to disease incidence in severe form.
\end{abstract}

(Received September 16, 1966)

\section{Introduction}

Incidence of a disease is governed by several factors operating together and conditioning its occurrence in a region. Presence of a susceptible host, inoculum concentration and optimal environment affect a disease by influencing host susceptibility or virulence of the pathogen. Environmentally conditioned susceptibility of a host is the tendency of non-genetic conditions, acting before infection to affect susceptibility of host plants to disease (Yarwood, 1959). It is directly affected by the age of host part and differs from disease to disease.

The pathogen Taphrina maculans Butler has been observed to infect most of the leaves of turmeric (Curcuma longa L.) plant except 1-2 leaves in the crown. Despite such a severe form of infection, precise time of infection relative to weather conditions and age of plants is not known. The present experiment was conducted to determine the effect of inoculum concentration in the soil, time of infection in relation to environment and susceptible age of the host leaves.

\section{Material and Methods}

The field was divided in 2 blocks; one was treated with supplemented primary inoculum and the other left untreated as control blank. Turmeric leaves severely infected with $T$. maculans were chopped into small pieces and spread evenly on the soil surface in the former after planting the rhizomes in the entire field. Observations and readings on the infected plants, infected leaves/plant and number of infection spots/leaf in both the blocks were taken after appearance of infection in the field. Three subsequent observations at 2 week intervals were taken to study the progressive disease development.

* College of Agriculture, Banaras Hindu University, India. 
Leaves of turmeric in the field were tagged at the time of emergence marking the date of their (complete unrolling. They were inoculated in progressive age groups in 3 replicates by smearing the culture suspension of $T$. maculans (Pavgi and Upadhyay, 1964) and covered with moistened polythene bags to provide moisture conditions. In another series, the leaves of near age were similarly inoculated at 2 week intervals from 15 July onward to determine the period of relative susceptibility. The inoculated leaves were tagged and left exposed in the open under prevailing weather conditions. Observations and counts of infection spots were taken] at 2 week intervals to assess the severity of disease incidence. The spots though clearly perceptible, were too immature at this stage to expulse out ascospores and induce secondary infection and confound the results. Severity of disease incidence was represented by the number of infection spots/sq. in. leaf area or by number of spots/leaf as feasible. A butter paper piece marked with 1 in. squares was superimposed on the infected leaves and spots covered within the area were counted and averaged. In cases of few spots, all were counted and averaged per sq. in. for the entire leaf area.

\section{Observations}

A. Soil-borne inoculum :

Earlier experiments have demonstrated that the pathogen $T$. maculans perpetuates in the form of ascostromata hibernating and oversummering in the leaf trash as well as through the heat resistant desiccated blastospores expulsed earlier in the soil and over the leaf surface (Upadhyay and Pavgi, 1967). The ascostromatic cells germinate with the start of monsoon rains and eject: their ascospore contents on the surrounding soil increasing the concentration of primary inoculum. Consequently, the disease appears first in the treated plots and gradually spreads in the whole field including the untreated ones; its intensity in the treated plots goes. higher than the untreated ones (Table 1). Earlier infection in the treated plots is due to the ascospores/blastospores from the germinating asci in the ascostromata, raised to the host leaves. by spattering rain drops. Soon after these (primary) infection spots mature expulsing their ascospores in the surrounding area, secondary infection starts in the field. Plants located even far away from the primarily infected ones thus get infected partly due to the air-borne secondary inoculum. Meanwhile, infection takes place in the untreated plots starting on the plants in the vicinity of the treated plots, later spreading to most of the plants. It is mainly due to the primary inoculum reaching them through field contamination. Further spread of the disease occurs. by secondary infection. Thus presence of infected leaf trash in the field considerably increases. the inoculum potential, helping earlier appearance of the disease with a higher number of primary infection spots.

Table 1. Progressive intensity of leaf spot disease of turmeric in treated and untreated plots.

\begin{tabular}{c|c|c|c|c|c|c|c}
\hline \multirow{2}{*}{$\begin{array}{l}\text { Date of } \\
\text { observation }\end{array}$} & \multicolumn{3}{|c|}{ Treated plots } & \multicolumn{3}{c}{ Untreated plots } \\
\cline { 2 - 7 } & $\begin{array}{c}\% \text { infect. } \\
\text { plants }\end{array}$ & $\begin{array}{c}\% \text { infect. } \\
\text { lvs/plnt }\end{array}$ & $\begin{array}{c}\text { av. no. } \\
\text { spt/leaf }\end{array}$ & $\begin{array}{c}\% \text { infect. } \\
\text { plants }\end{array}$ & $\begin{array}{c}\% \text { infect. } \\
\text { lvs/plnt. }\end{array}$ & $\begin{array}{c}\text { av. no. } \\
\text { spt/leaf }\end{array}$ \\
\hline $14-9-65$ & 14.9 & 21.9 & 36 & 2.5 & 19.3 & 11 \\
$29-9-65$ & 32.5 & 24.2 & 43 & 6.9 & 16.6 & 27 \\
$14-10-65$ & 68.9 & 35.7 & 129 & 23.2 & 27.2 & 57 \\
\hline
\end{tabular}


Table 2. Intensity of leaf spot disease on turmeric leaves inoculated at progressive time periods.

\begin{tabular}{c|c}
\hline \hline Date of inoculation & Av. no. spots/sq. in. leaf area \\
\hline 15 July & 3 \\
1 August & 136 \\
15 August & 360 \\
1 September & 304 \\
15 September & 234 \\
1 October & 184 \\
15 October & 115 \\
1 November & 80 \\
15 November & 27 \\
\hline
\end{tabular}

\section{B. Time of infection :}

Humid rainy weather has been observed to favor infection of the host plants. A relatively higher number of infection spots develop on the leaves inoculated on 15 August and 1 September due to the humid rainy weather prevalent during this period (Table 2). A continuous spell of this weather during August-September is conducive to germination of blastospores raised from the soil to the leaf surface and subsequent development of infection spots. Isolations of ascoor blastospores from soil around the infected leaves are generally associated or even masked by the rapid growth of contaminants, although typical colonies can be scooped out under microscope. Agar pieces containing these colonies, when inverted over young turmeric leaves in moisture chambers, produce typical infection spots in 10-12 days. Inoculations made by smearing cultures in October and November after the rainy season continue to bring about the infection due to dew deposit during late nights and early mornings helping germination of ascospores/blastospores.

Earlier observations show that an adequate amount of moisture is requisite for initiation of germination of ascogenous cells to produce asci and ascospores. The moist weather with intermittent rains ideally provides the condition further for release of the spore inoculum from the oversummering ascostromata. A shift in the start of monsoon rains, therefore, causes a corresponding change in the time of infection. A delay in disease incidence was reported in $T$. deformans as well due to unusual weather at the time of its normal occurrence (Mix, 1925).

The day temperature during August-September ranges between $25-30^{\circ} \mathrm{C}$. The optimal temperatures for ascospore discharge and subsequent growth of the pathogen fall within this range, indicating its suitability for multiplication of ascospore inoculum as well as infection of the crop. This period having optimal levels both for moisture and temperature requirements of the pathogen is most critical for a disease-free crop growth. The infection spreads very rapidly in a crop stand in which the disease has already appeared, involving all other plants in the field within a short period.

\section{Age of host leaves :}

Turmeric leaves become susceptible to infection 2 weeks after unrolling. Young leave, upto 7 days after unrolling show lesser number of infection spots due to a fine waxy coating on their surface. Smearing the surface with a dilute detergent solution of 'Surfactol-100'* ( 1 drop in 100 $\mathrm{ml}$ of dist. water) prior to inoculation considerably increases the number of infection sites. The susceptibility of turmeric leaves is maintained for about a month and then gradually declines with advancing age acquiring partial resistance (Table 3), probably due to addition of carbo-

\footnotetext{
* Rohm and Haas Company, Washington Square, Philadelphia. Pa. U.S.A.
} 
Table 3. Intensity of leaf spot disease on turmeric leaves inoculated at progressive age after unrolling.

\begin{tabular}{c|c}
\hline Age in days at inoculation & Avg. no. spots/sq. in. leaf area \\
\hline 7 & 64 \\
15 & 215 \\
21 & 232 \\
30 & 213 \\
45 & 175 \\
60 & 85 \\
\hline
\end{tabular}

hydrates to the cell walls of the tissues rendering them harder for the penetrating germ tubes of the blastospores. Relative susceptibility of the leaves is lowered with maturity but does not attain resistance or immunity. Thus the leaves, which have escaped infection in the early stages of their growth due to late incidence, get infected even later, though with lesser severity.

\section{Discussion}

The factors affecting the disease incidence are interdependent for their influence on the incidence of leaf spot disease of turmeric. Infected plant debris left in the fields becomes effective only when optimal environment for germination of the ascostromatic cells prevails to raise the inoculum potential. Adverse conditions such as prolonged rain water accumulation in the field degrade the ascostromata on leaf trash by rotting and action of moulds thus keeping the incidence at an insignificant level. Maximum utilization of a suitable spell of weather by the pathogen is possible only when the effective soil inoculum is high enough to initiate an earlier appearance of the disease with a higher number of primary infection spots. The turmeric leaves remain susceptible over a considerably longer period irrespective of their age, provided the environment of temperature and moisture and the inoculum potential are at an optimum level. Control measures may, therefore, be directed to reduce the primary inoculum potential by destruction of plant debris in the turmeric fields, after the rhizomes are harvested.

\section{Acknowledgement}

The first author (RU) expresses his gratitude to The Council of Scientific and Industrial Research, New Delhi for the award of a Junior Research Fellowship.

\section{Literature Cited}

1. Mix, A. J. (1925). Phytopathology 15: 244-245.

2. Pavgi, M. S. and R. Upadhyay (1964). Sci. \& Cult. 30: 558-559.

3. Upadhyay, R. and M. S. Pavgi (1967). Phytopath. z. (59: 136-140).

4. Yarwood, C. E. (1959). In Plant Pathology. Vol. I: 521-562. (Edit. by J. G. Horsfall and A. E. Dimond). Academic Press Inc., New York. 


\section{和文摘要}

Taphrina maculans によるウコン斑点病の発生に及ぼす $2 ， 3$ の要因

\section{Rajendra Upadhyay $\cdot$ M. S. Pavgl}

Taphrina maculans Butler によるウコン (Curcuma longa L.) 斑点病の発生程度は, 環境條件と土壌 中の感染源の量とに影響されることが示された。葉令により感受性に多少の羑異は認められたが，葉は長い 間䍜病性であって湿度條件に恵まれている間は感染が抢こるので，葉令は重要な意味をもたなくなる。病気 の発生時期の早さや激しさは，土壤中の有効感染源の密度によって左右される。当地方で 8 9月に多い25 $\sim 30^{\circ} \mathrm{C}$ の気温と多湿で量りの天候は本病の激発を助長する。 